\title{
The trees in the middle of Paradise (Gn 2:9) during the Great Lent: Orthodox hymnography as biblical interpretation
}

\begin{tabular}{|c|c|}
\hline \multicolumn{2}{|c|}{$\begin{array}{l}\text { Author: } \\
\text { Constantin H. Oancea } \\
\end{array}$} \\
\hline \multicolumn{2}{|c|}{$\begin{array}{l}\text { Affiliations: } \\
\text { 'Department of Orthodox } \\
\text { Theology, Faculty of Theology, } \\
\text { Lucian Blaga University of } \\
\text { Sibiu, Sibiu, Romania }\end{array}$} \\
\hline \multicolumn{2}{|c|}{$\begin{array}{l}{ }^{2} \text { Department of Systematic } \\
\text { and Historical Theology, } \\
\text { Faculty of Theology and } \\
\text { Religion, University of Pretoria, } \\
\text { Pretoria, South Africa }\end{array}$} \\
\hline \multicolumn{2}{|c|}{$\begin{array}{l}\text { Research Project Registration: } \\
\text { Project Leader: J. Pillay (1) } \\
\text { Project Number: } 04653484\end{array}$} \\
\hline \multicolumn{2}{|c|}{$\begin{array}{l}\text { Description: } \\
\text { The author is participating as } \\
\text { the research associate of Dean } \\
\text { Prof. Dr Jerry Pillay, Faculty of } \\
\text { Theology and Religion, } \\
\text { University of Pretoria. }\end{array}$} \\
\hline \multicolumn{2}{|c|}{$\begin{array}{l}\text { Corresponding author: } \\
\text { Constantin H. Oancea, } \\
\text { constantin.oancea@ulbsibiu.ro }\end{array}$} \\
\hline \multicolumn{2}{|c|}{$\begin{array}{l}\text { Received: } 05 \text { Apr. } 2021 \\
\text { Accepted: } 18 \text { June } 2021 \\
\text { Published: } 17 \text { Aug. } 2021\end{array}$} \\
\hline \multicolumn{2}{|c|}{$\begin{array}{l}\text { How to cite this article: } \\
\text { Oancea, C.H., 2021, 'The } \\
\text { trees in the middle of } \\
\text { Paradise (Gn 2:9) during the } \\
\text { Great Lent: Orthodox } \\
\text { hymnography as biblical } \\
\text { interpretation', HTS } \\
\text { Teologiese Studies/ } \\
\text { Theological Studies } \\
77(4) \text {, a6699. https://doi. } \\
\text { org/10.4102/hts.v77i4.6699 }\end{array}$} \\
\hline \multicolumn{2}{|c|}{$\begin{array}{l}\text { Copyright: } \\
\text { (c) 2021. The Authors. } \\
\text { Licensee: AOSIS. This work } \\
\text { is licensed under the } \\
\text { Creative Commons } \\
\text { Attribution License. }\end{array}$} \\
\hline \multicolumn{2}{|l|}{ Read online: } \\
\hline 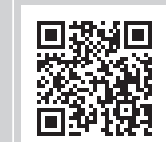 & $\begin{array}{l}\text { Scan this QR } \\
\text { code with your } \\
\text { smart phone or } \\
\text { mobile device } \\
\text { to read online. }\end{array}$ \\
\hline
\end{tabular}

The article examines the interpretation of the Scripture in Byzantine hymnography during the Great Lent. Some notable recent contributions focus on Andrew of Crete's and Romanos the Melodist's compositions, illustrating the hymnographic way of understanding the Scriptures. The author of this study presents a selection of stanzas from hymns of the Triodion that refer to the trees of Paradise. Hymnography perceives the trees in Genesis 2-3 in direct connection with the cross. Only rarely is the tree of life a metaphor for Jesus, as the shadow of the tree of the cross is seldom a metaphor for protection. Another interesting aspect in relation to hymnography is the fact that it represents a type of intertextual exegesis of biblical texts. Hymnographers interpret passages from Genesis by using texts from Psalms, Prophets and especially from the New Testament, combining images and biblical texts in the depiction of liturgical moments.

Contribution: Compared with previous research, this article discusses some rarehymnographic interpretations (shadow of the cross; cross in the middle of the earth). The analysis accentuates that the hymnic approach to the Scripture is a form of intertextual exegesis.

Keywords: trees of Paradise; Byzantine Hymnography; cross; Triodion; Lent; intertextuality.

\section{Introduction}

The Eastern Orthodox hymnography can be viewed as a form of interpretation of the Bible. The use of the Scripture in worship reveals how believers understand biblical texts in the act of worshipping God. Perhaps we are not mistaken if we say that, in the first millennium, Christians in the Eastern Church knew the Bible more from ritual than from reading it. Reading the Holy Scriptures was the privilege of a minority including clergy, scholars and wealthy Christians (Wallraff 2013:12). Probably not only the low degree of literacy was decisive in this matter (Gamble 1995:5-6), but also financial considerations. Churches and monasteries had libraries where Bible books could be read. However, the costs of a codex generally exceeded the annual income of common people, for example of a Byzantine scribe (Mratschek 2000:372-373), so that only wealthy Christians could afford private possession of books.

During liturgy, the Old Testament was accessible for ordinary Christians in the form of biblical readings. If the text of the Gospels and Epistles was read almost in its entirety during a liturgical year, only certain passages from the Old Testament were read, as is the case in today's Orthodox church service. In addition to these readings, iconography has also augmented the knowledge of the Scripture (Miller 2010). The Bible was also accessible to the common man through sermons and songs. Basil the Great (330-379 CE) was convinced that the teachings of the Bible are easier to remember in songs rather than in scholarly speeches:

For, never has any one of the many indifferent persons gone away easily holding in mind either an apostolic or prophetic message, but they do chant the words of the psalms, even in the home, and they spread them around in the market place ... (trans. Way 1963:152)

In this article, some Byzantine stanzas used during the Great Lent that refer to Genesis 2-3 are analysed. Research on how Byzantine hymnography uses biblical texts is a relatively recent undertaking (Bucur 2007; Costache 2009, 2020; Krueger 2014; Mellas 2017). Bucur (2007) considers hymnography as a type of biblical interpretation close to the category 'Rewritten Bible'. Analysing hymnography as exegesis to Genesis 1-3, Costache states that its hermeneutical method is 'the

Note: Special Collection: Lucian Blaga University, Sibiu, Romania, sub-edited by Daniel Buda (Lucian Blaga University) and Jerry Pillay (University of Pretoria). 
consistent aim of rewriting the foundational narratives ... through an existential key that makes them personally and ecclesially relevant' (Costache 2009:44). Krueger offered a comprehensive analysis of hymnography pursued in the historical process of the formation and development of the Byzantine ritual. Ritual is a form of biblical re-enactment, which contributes to the formation of the self (Krueger 2014). Analysing the hymns of the cross composed by Romanos the Melodist, Mellas (2017) concludes that hymnography evokes the nostalgia for the paradise of the faithful, but at the same time it represents the invitation to participate to an eschatological communion with the scriptural characters.

The author has grouped the stanzas that are analysed according to recurring themes and motives in the Triodion the service book used during the Great Lent in the Eastern Church. Because liturgical texts on the trees in Genesis 2-3 are numerous, the author has selected some stanzas that are suggestive for these themes. So as to make reference easier, liturgical texts have been numbered as T1, T2 ... T13. The English translation of the texts is rendered after The Lenten Triodion (Mary \& Ware 1978, 1979). Where the discussion also requires the rendering of the Greek text, the author has used the online Greek Triodion, available on the website of the Greek Orthodox Archdiocese of America (hereinafter abbreviated TPI $\Omega \Delta \mathrm{ION}$ n.d.).

\section{The trees of Paradise in the biblical text}

The trees in the Garden of Eden are mentioned in chapters 2 and 3 of Genesis. The relevant passages listed below are extracted from the paroimiai - biblical lessons used in Orthodox worship. Etymologically, paroimiai is derived from the Greek name of Book of Proverbs because lessons from this book are frequent in the Byzantine rite. However, a paroimia can designate any Old Testament reading, thus also a reading from Genesis (Pentiuc 2014:359). The text of these relevant passages is from the online Greek Triodion, which does not differ from the one in the critical edition of the Prophetologium (eds. Høeg \& Zuntz 1940). ${ }^{1}$

\section{Genesis 2:9:}

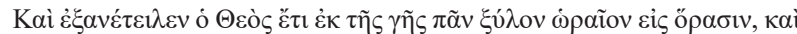

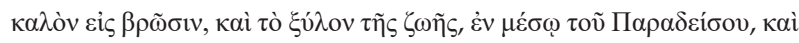

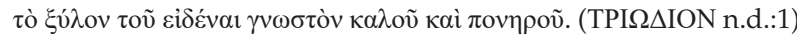

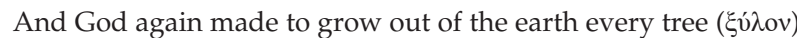
beautiful to the sight and good for food; and the tree of life in the midst of the garden, ${ }^{2}$ and the tree of knowing what is to be known of good and evil. (Author's translation)

\section{Genesis 2:16-17:}

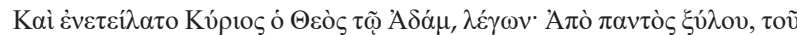

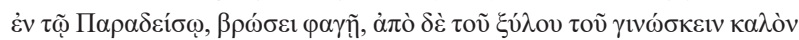

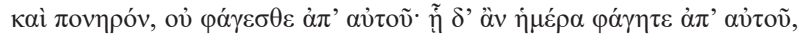

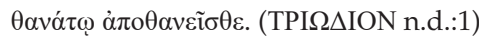

\footnotetext{
1.The passages are from the following paroimiai: Genesis 2:1-19 - first week, Friday, Vespers (Thursday evening): Genesis 2:20-3:20 - first week, Saturday, Vespers (Friday evening); Genesis 3:21-4:7 - second week, Tuesday, Vespers (Monday evening).
}

2.Lit. 'Paradise'.
And Lord God commanded Adam saying, 'From every tree of the garden you may eat for food; but from the tree of knowing good and evil, you shall not eat from it; in whatever day you eat from it, you shall die by death'. (Author's translation)

\section{Genesis 3:6:}

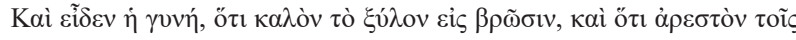

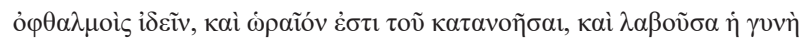

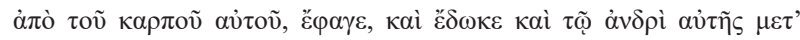

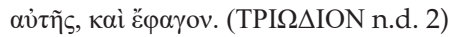

And the woman saw that the tree was good for food, and that it was pleasing for the eyes to see and that it was beautiful to contemplate, and taking from its fruit, the woman ${ }^{3}$ ate; and she also gave to her man with her, and they ate. (Author's translation)

Genesis 3:22:

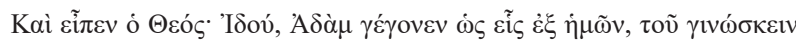

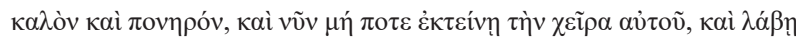

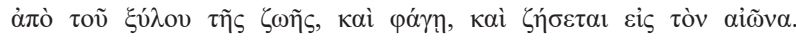

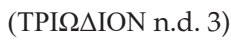

And Lord God said, 'See, Adam has become like one of us, knowing good and evil. And now perhaps he might stretch out his hand and take from the tree of life and eat, and he will live forever'. (Author's translation)

\section{Paradise trees in hymnography}

Christological interpretations of the two trees in Paradise are widespread in the writings of the Church Fathers (Charalampidis 1995:62-67; Daniélou 1961:33-47). The earliest interpretations of the cross as a symbol of the tree of life appear in the 2nd-century authors Justin Martyr (Dialogus cum Tryphone 86.1; eds. Roberts, Donaldson \& Coxe 1885) and Irenaues of Lyon (The Demonstration of the Apostolic Preaching 34; transl. Robinson 1920).

The contrast between the tree of damnation (the tree of knowledge in Eden) and the tree of salvation (the cross) was a favourite theme during the Great Lent. It was in this time of the year that John Chrysostom preached on the Book of Genesis. He stated that the tree of salvation, that is, the cross, destroyed the evils brought by the other tree (Homiliae in Genesim 7; ed. Brottier 1998:324-325). The idea recurs in several of the Easter homilies of the 5th and 6th centuries (Hesychius of Jerusalem, Ps. Chrysostom, Basil of Seleucia, Leonce of Constantinople) edited by Aubineau (ed. 1972) in Sources Chrétiennes 187 and in hymns that Romanos the Melodist composed for the Holy Week (Hymns 36, 38 and 39; ed. Grosdidier de Matons 1967).

Byzantine hymnographers also assert the connection between the trees of Paradise and the cross of the Saviour. The cross is called 'tree'. Both the trees and the cross are referred to as 'wood'. The common denominator of the two trees of Eden and the cross is the substance of which they are made: wood. In both Hebrew and Greek, צy ('ẹs) and gúnov mean both tree and wood as substance (Liddell et al. 1996:1191-1192; Ringgren, Nielsen \& Fabry 2001:266-268). Thus, the trees of Genesis can alternatively be called 'the wood of life and the wood of the knowledge of good and evil'.

3.Compared with LXX Rahiphs, the paroimia adds " the woman" (ท vuvi)), without influencing the meaning of the phrase. 
Presumably the hymnographers commented on the connection between the wood of the cross and the trees of Eden in view of the fact that, since the 4 th century, there was a ritual of honouring fragments of the True Cross in Jerusalem and in Constantinople (Frolow 1961; Köpf 1990). In 348 CE, when Cyril of Jerusalem was giving his lectures in the Church of the Holy Sepulchre in Jerusalem, fragments of the wood of the cross were spread in various parts of the world (Catechesis 4.10; 13.4; trans. Gifford 1894:21, 83). About 400 CE, Rufinus informs us of a part of the True Cross being moved to Constantinople, while another part remained in Jerusalem (Historia ecclesiastica 10.7-8; ed. Holder 1889:46-47). The veneration of the True Cross at Jerusalem is described by the pilgrim Egeria (Peregrinatio 37.1; ca. 380 CE; ed. Geyer 1898:88). In the 7th century, pilgrims from Egypt came to Jerusalem to worship the wood on which the Saviour was crucified (Sophronius of Jerusalem, Vita S. Mariae Aegyptiae 19-23; ed. Migne 1863:vol. 87/3:3712-3713). ${ }^{4}$ A procession with 'the portions of the precious and Life-giving Cross' during the siege of Constantinople by the Persians (626 CE) is mentioned by the synaxarion on Saturday, the 5th Week of the Great Lent. Therefore, we can assume that it was not uncommon for someone in Byzantium to refer to the cross as the 'wood (of the cross)'.

\section{The cross and the tree of the knowledge of good and evil}

T1 (3rd Sunday, Vespers on Saturday evening, at 'Lord I have cried'):

Come, Adam and Eve, our first father and mother, who fell from the choir on high through the envy of the murderer of man, when of old with bitter pleasure ye tasted from the tree in Paradise. See, the Tree of the Cross, revered by all, draws near! Run with haste and embrace it joyfully, and cry to it with faith: $\mathrm{O}$ precious Cross, thou art our succour; partaking of thy fruit, we have gained incorruption; we are restored once more to Eden, and we have received great mercy. (Mary \& Ware 1978:335)

T2 (3rd Sunday, Matins, Ode 6, Ikos):

Pilate set up three crosses in the place of the Skull, two for the thieves, and one for the Giver of Life. Seeing Him, hell cried to those below: ' $\mathrm{O}$ my ministers and powers! Who is this that has fixed a nail in my heart? A wooden spear has pierced me suddenly, and I am torn apart! Inwardly I suffer; anguish has seized my belly and my senses. My spirit trembles, and I am constrained to cast out Adam and his posterity! A tree brought them to my realm, but now the Tree of the Cross brings them back again to Paradise'. (Mary \& Ware 1978:343)

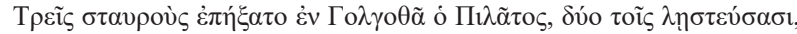

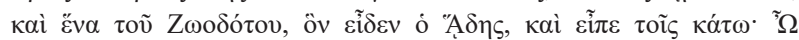

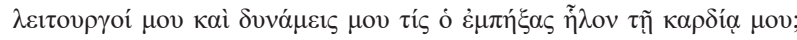

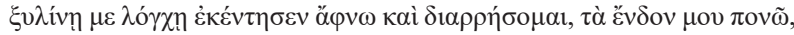

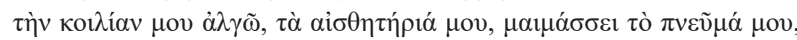

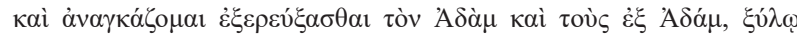

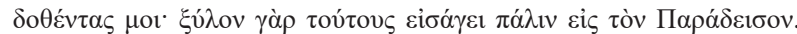
(TPI $\Omega$ ION n.d. 4)

Many stanzas develop the contrast between the tree of knowledge and the cross of Christ. Eating from the old tree 4.The life of St. Mary of Egypt is read in the Byzantine rite on Thursday, in the 5 th week of Lent. resulted in the loss of Paradise. People became prisoners of hell (T2).

The 3rd Sunday of Lent is dedicated to the veneration of the cross, so that most of the stanzas revolve around this theme, starting with the Vespers celebrated on Saturday evening. The hymnographer uses dramatic procedures, addressing, in an imaginary dialogue, Adam and Eve, calling them to embrace the wood of the cross, to taste its fruit, to acquire the true Eden (T1).

$\mathrm{T} 2$ is identical to one of the hymns composed by Romanos the Melodist, the best-known representative of Byzantine hymnography of the 6th century (Hymn 38.3.1; ed. Grosdidier de Matons 1967:286-288; cf. also Iorga 2016:94-95). ${ }^{5}$ Romanos' most notable rhetoric device was dramatic dialogue (Mellas 2017), as demonstrated by T2. Hell (Hades) is one of the dramatis personae, lamenting because it has been pierced by the wood of the cross. To describe the agony of Hades, Romanos paraphrases the prophetic lament in Jeremiah 4:19:

\section{Jr 4:19 LXX}

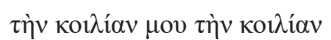

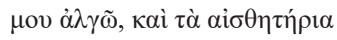

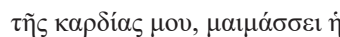

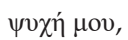

$\sigma \pi \alpha \rho \alpha ́ \sigma \sigma \varepsilon \tau \alpha i \dot{\eta} \kappa \alpha \rho \delta i ́ \alpha \mu \mathrm{ov}$, ... (ed. Rahlfs 1979)

I am pained in my bowels, my bowels, and the sensitive powers of my heart; my soul is in great commotion,

my heart is torn...

(trans. Brenton 1870)
T2

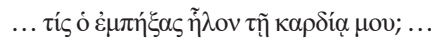

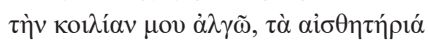

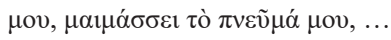

Who is this that has fixed a nail in my heart? ...

I am pained in my bowels and my senses; my spirit is in great commotion ...
In addition, the hymnographer combines the piercing motif with that of the womb of Hades, in which Adam and Eve were held. T2 uses terminology from Jonah 2:3 LXX

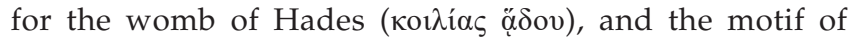
Hades' greed is probably taken from Isaiah 5:14. The physiological and mental states described are both those of being stabbed and poisoned or intoxicated: abdominal pain ('I am pained in my bowels'), confusion ('my spirit is in great commotion') and nausea ('I am constrained to cast out Adam and his posterity'). The images highlight the biblical culture and artistic refinement of Romanos. The Hades-Paradise dichotomy also reflects the contrast between the tree of the knowledge of good and evil and the cross, brought out even more distinctly by a wordplay: 'Those given to me by a tree, a tree brings them back again

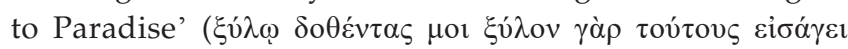

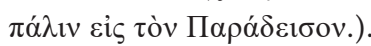

5.The indications in the Triodion mention Theodore the Stoudite (759-826 CE) as the author of the canon of Sunday Matins (see Mary \& Ware 1978:337). Obviously, Theodore only edited this earlier hymn. 


\section{The cross and the tree of life}

T3 (3rd Sunday, Vespers on Saturday evening, at 'Lord I have cried'):

Hail! Life-giving Cross, the fair Paradise of the Church, Tree of incorruption that brings us the enjoyment of the eternal glory.... (Mary \& Ware 1978:334)

T4 (3rd Sunday, Matins, Ode 5):

The Church has been revealed as a second Paradise, having within it, like the first Paradise of old, a tree of life, Thy Cross, O Lord. By touching it we share in immortality. (Mary \& Ware 1978:341)

T5 (3rd Sunday, Matins, Ode 3):

Thy Cross, O Lord, is holy, and brings healings to those who are in sickness through their sins. Venerating it, we fall before Thee: have mercy upon us. (Mary \& Ware 1978:339)

T6 (3rd Sunday, Matins, Ode 9):

I died through a tree, but I have found in thee a Tree of Life, O Cross of Christ! ... (Mary \& Ware 1978:345)

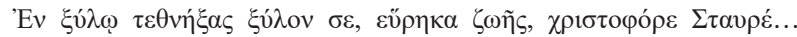
(TPI $\Omega$ ION n.d. 4).

The cross is associated or even identified with the tree of life in Paradise. Hymnic texts that reflect this theme are concentrated on the 3rd Sunday of Lent. Believers are called to worship the cross and shout: 'Rejoice, tree of life!' (T3). The cross is personified and addressed in a manner that is specific for the saints in Byzantine hymns. 'The beautiful Paradise of the Church' and 'tree of incorruption' are images derived from the biblical text in Genesis 2-3.

T4 uses typological exegesis. The Church is considered a second Paradise, whereas the first Paradise is not annulled. The tree of life in the first Paradise corresponds to the tree of the cross in the second Paradise. Adam failed to eat from the tree of life to overcome death, whereas every Christian received immortality by touching the wood of the cross. By 'touching the Cross', T3 aims not only at the physical gesture, but probably also at the act of eating from the tree of cross, i.e., assimilating the saving sacrifice of the Son of God.

T5 affirms the healing power of the cross. Such an assertion is not directly derived from Genesis 2-3. In the author's opinion, the hymnographer has in mind the image of the tree of life in Revelation 22:2, described as having healing leaves. ${ }^{6}$ This connection assumes that the hymnographer had a holistic view of the Bible, in which the Paradise at the beginning and the Paradise at the end are in a symmetrical relationship, Christ being the Alpha and the Omega, the beginning and the end. Presumably the hymnographer noticed the chiastic symmetry of the Genesis 2 and Revelation 22:

Gn 2:9: ... the tree of life also in the midst of the garden, ... Gn 2:10: A river flows out of Eden to water the garden... $\operatorname{Rv} 22: 2$ : Then the angel showed me the river of the water of life...

$\operatorname{Rv} 22: 2:$ On either side of the river is the tree of life...

In T6, the believer is invited to identify himself with Adam. The contrast is developed between the old tree of the 6.Revelation 22:2 takes the image from Ezekiel 47:12. knowledge of good and evil and the new tree of life, which is the cross. When tasting from the tree of knowledge, Adam ate from the fruit of death. Referring to the cross as 'Christ

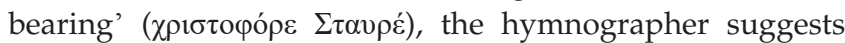
that Christ is the fruit of the tree of the cross. Because Christ is the life (Jn 11:25; 14:6), the tree that bears him is the tree of life for Christians.

\section{The cross in the middle of the earth}

\begin{abstract}
T7 (3rd Sunday, Matins, Synaxarion)
... And since the Cross is called, and indeed is, the Tree of Life, it is the very tree that was planted in the Garden of Eden. So it is fitting that the Holy Fathers have planted the Tree of the Cross in the middle of the Forty Day Fast to commemorate both Adam's tasting of its sweet fruit and of its being taken from us in favor of the Tree of the Cross, tasting of which we shall in no way die, but will have even greater life. (Lenten Synaxarion 2016)
\end{abstract}

T8 (4th week, Wednesday, Matins, Ode 9)

Thy side was pierced with a spear, and Thou hast poured upon us a fountain of forgiveness. Thou wast nailed to a tree, $\mathrm{O}$ Loving Lord, and Thou hast destroyed in the midst of the earth the condemnation that came through a tree. On this middle day of the Fast, we embrace the Wood of the Cross and sing the praises to Thy goodness. (Mary \& Ware 1979:202)

T9 (4th week, Friday, Matins, Ode 4)

In the middle of the Fast we see exalted in our midst the precious Cross, on which Thou wast lifted by Thine own choice in the middle of the earth, $\mathrm{O}$ Lord supreme in goodness and love. Through its veneration the world is sanctified, and the hosts of demons put to flight. (Mary \& Ware 1979:218-219)

T10 (5th week, Thursday, Great Canon, Ode 4)

O Creator, Thou hast worked salvation in the midst of the earth, that we might be saved. Thou wast crucified of Thine own will upon the tree; and Eden, closed till then, was opened .... (Mary \& Ware 1978:392)

A peculiar statement in hymnography is that the cross on which Jesus was crucified was in the middle of the earth, just as the tree of knowledge was in the middle of Eden (T7, T8). The idea is repeatedly stated in the 4 th week of Lent, the week that liturgically marks the passage of the first half of Lent. Thus, in the midst of Lent, Christians are called to worship the cross set in the midst of all, as in the midst of the earth (T9). The biblical image of the trees in the middle of Eden is used in the synaxarion (T7) to explain why the cross is honoured in the middle of Lent.

The image of the cross as the centre of the earth has a symbolic dimension: Jesus' sacrifice on the cross is the centre of Christian faith. However, this image may be derived from a tradition well attested in the first millennium: the belief that Golgotha once stood in the place of Eden, right in the middle of the earth.

In fact, after Constantine the Great built the Church of the Holy Sepulchre in Jerusalem, Jewish traditions related to the Temple were transferred over the Church of the Holy Sepulchre (Donner 1977:9-10; Küchler 2007:480-481). Late Judaism located the Temple in the middle of the earth, the 
temple mountain being the highest mountain in the world. Placed beneath the Holy of Holies, the foundation stone ('Gründungsstein') was perceived both as the navel of the earth and the gateway to heaven (Donner 1977:10). Starting with the 4th century, or even earlier, such perceptions were Christianised (Boicu 2017:100-112). By that time, Mount Golgotha was considered to lie in the centre of the world. Origen (c.185-c.253 CE) claims that there was a Jewish tradition about Golgotha as the place of Adam's burial (In Matthaeum commentariorum series 126; ed. Migne 1862:1777). Conceptions related to the foundation stone of the Temple were transmitted on the rock of Golgotha, which in the basilica founded by Constantine was under the open sky, between Martyrion and Anastasis (Donner 1977:10). Breviarius de Hierosolyma (6th century) states that the rock of Golgotha was the place where Adam was created (ed. Geyer 1898:154).

In the 4th century, Cyril of Jerusalem recalls the tradition of Golgotha as the centre of the world in his lectures addressed to those preparing for baptism:

He stretched out His hands on the Cross, that He might embrace the ends of the world; for this Golgotha is the very centre of the earth. It is not my word, but it is a prophet who hath said, Thou hast wrought salvation in the midst of the earth [Ps 74:12 / 73:12 LXX] (Catechesis 13.28; trans. Gifford 1894:90)

It is noteworthy how both Cyril and T10 interpret one biblical text through another. The tradition that Golgotha is the centre of the world is based on Genesis 2:9, interpreted through Psalm 74, both texts being understood as referring to the crucifixion. Thus, within Psalm 74:12 Cyril and the hymnographer emphasise those elements that not only remind of Genesis 2, but also refer to Jesus' crucifixion:

$\begin{array}{lll}\begin{array}{l}\text { Genesis 2 } \\ \text { God worked ... }\end{array} & \begin{array}{l}\text { Psalm 74 } \\ \text { God worked } \\ \text { salvation }\end{array} & \begin{array}{l}\text { New Testament } \\ \text { Christ worked } \\ \text { salvation } \\ \text { on Golgotha }\end{array} \\ \begin{array}{l}\text { in the midst of the } \\ \text { garden }\end{array} & \begin{array}{l}\text { in the midst of } \\ \text { the earth }\end{array} & \begin{array}{l}\text { on } \\ \text { ing }\end{array}\end{array}$

\section{The shadow of the cross}

\footnotetext{
T11 (3rd Sunday, Matins, Synaxarion):
}

Also, as those who have travelled a long hard road, weighed down by the labours of their journey, in finding a shady tree, take their ease for a moment and then continue their journey rejuvenated, so now in this time of the Fast, this sorrowful and laborious journey, the Holy Fathers have planted the life-giving Cross, for our relief and refreshment, to encourage and make easier the labors that lie ahead. (Lenten Synaxarion 2016)

Shadow is used in the Bible as a metaphor to express protection (Is 49:2; Hs 14:8-9; Ps 36:8; 91:1). Because of the protection they claim to offer, kings are compared to trees (Ezk 31:3; Dn 4:12). Ironically, Jotham compares Abimelech to a thorn because he cannot provide shade, that is protection for the people of Shechem (Jdg 9:15).

Given this biblical metaphor, new associations between the cross and the trees of Paradise are possible. Byzantine hymnographers also imagined what the biblical text does not explicitly say: that the trees in the garden of Eden offered the first humans not only food but also shade to rest during the day. Hymnographers also transposed this image on the tree of the cross, which offers protection, rest and reinforcement during Lent (T11).

The 40 days of Lent might recall the hard 40-year journey of Israel through the desert. In Byzantine practice, the 40 days included Saturdays and Sundays, but excluded Lazarus Saturday, Palm Sunday and the Holy Week, considered as a special pre-paschal fast (Schmemann 1990:135-137). Viewed this way, the 40-day Lent has 6 weeks, but only 5 Sundays, the 3rd Sunday being in the middle of Lent. Presumably, the synaxarion builds on this conception to explain why the 3rd Sunday is dedicated to the Cross. Through metaphorical mapping, the synaxarion depicts Lent as laborious journey and the cross as a shading tree that offers rest in the middle of this journey.

\section{Jesus, the tree of life}

T12 (5th Week, Saturday, The Akathist Hymn, Ode 5):

Rejoice, fiery chariot of the Word;

Rejoice, Lady, living paradise,

holding in your midst the Lord, the Tree of Life!

His sweetness quickens all who eat with faith,

although they were enslaved to corruption. (Mary \& Ware 1978:432)

T13 (6th Week, Wednesday, Matins, Ode 8):

Thou comest again, O Christ, to Judaea, which seeks to kill Thee the Tree of Life upon the Tree of the Cross; for it is Thy will to make immortal those who had been slain by eating from the tree. (Mary \& Ware 1979:285)

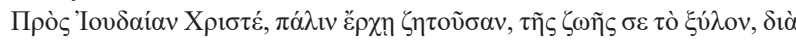

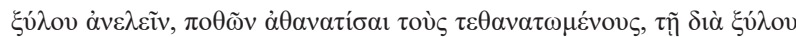

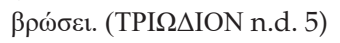

Several images from Genesis are used in T12: Paradise, the tree of life in the middle of Paradise, eating from the tree of knowledge. The hymnographer uses Biblical images as an allegory of the pregnant Virgin. Although in Byzantine iconography the Virgin is depicted holding the child Jesus in her arms, the hymnographer seems to refer here to the Annunciation. According to the revised Julian calendar, the Feast of Annunciation always falls during Lent. Virgin Mary, who receives the divine Logos in her womb, is at the centre of the celebration. The hymnographer depicts this scene by using the image of Paradise, in the middle of which is the tree of life. Thus, the tree of life is identified with Jesus. Furthermore, the allegory has an eucharistic symbolism: believers eat from Jesus - the tree, who grants life to those who were enslaved by the eating from the tree of knowledge.

T9 also uses the image of the tree of life as a metaphor for Jesus in a context that is dominated by images of death: Jesus accepts death so that those who have died by eating from the tree of knowledge become immortal.

Judaea appears in a negative image, desiring to kill the tree of life through the tree of the cross. In this respect, T13 bears 
resemblance to certain Byzantine hymns used during Holy Week. These are considered controversial as they contain anti-Jewish statements. Whether these hymns should be removed today from liturgy or they should be preserved is a discussion that still seems far from being concluded, as recent contributions have shown (Azar 2015; Bucur 2017; Ioniță 2019; Mourtzios 2019).

On the contrary, we must note that $\mathrm{T} 13$ is read in the 6 th week of Lent. The resurrection of Lazarus is to be commemorated some 3 days later, on the Saturday of this week. Consequently, the hymn refers to the biblical episode recounted in John 11, from which it paraphrases verses 7-8 and 25-26.

\begin{abstract}
Jn 11:7-8:
Then after this he said to the disciples, 'Let us go to Judea again.' The disciples said to him, 'Rabbi, the Jews were just now trying to stone you, and are you going there again?'
\end{abstract}

\section{Jn 11:25-26:}

Jesus said to her, 'I am the resurrection and the life. Those who believe in me, even though they die, will live, and everyone who lives and believes in me will never die...'. (NRSV)

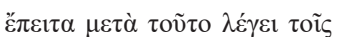

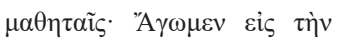

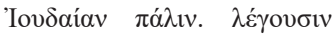

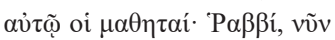

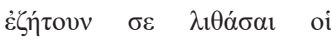

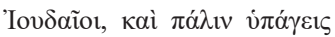

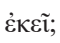

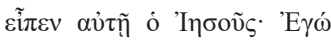

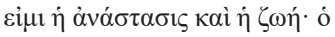

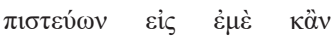

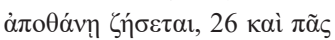

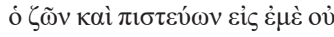

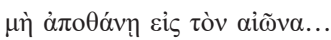
(Holmes 2011-2013)

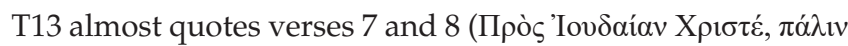

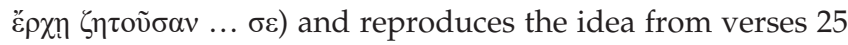
and 26 by the repeated use of death terminology ( $\dot{\alpha} v \varepsilon \lambda \varepsilon \tilde{v} v$, $\dot{\alpha} \theta \alpha v \alpha \tau i ́ \sigma \alpha l, \tau \varepsilon \theta \alpha v \alpha \tau \omega \mu \varepsilon ́ v o v \varsigma)$. Thus, it becomes obvious that the hymnographer does not intend to develop an anti-Jewish rhetoric in $\mathrm{T} 13$, but he interprets the Johannine narrative through images from Genesis 2-3.

\section{Conclusion}

Church hymns reveal multiple possibilities of understanding biblical texts. Most often, hymnographers interpret the trees of Paradise in direct connection with the cross. Less frequently, the tree of life is a metaphor for Jesus. The shadow of the cross is a metaphor having the trees of Eden as source domain. Generally, a close relationship can be observed between hymnographic and patristic exegesis. In most cases, we may presume that church fathers set the tone and that their writings were sources for hymnographers. Nevertheless, hymnography reveals itself as a creative exegesis of biblical texts, and some of its interpretations, for example using the shadow of Paradise trees as a metaphor of the cross, are perhaps not found in patristic exegesis.

In addition to the use of typology, allegory and metaphor, hymnography can arise interest as intertextual exegesis of the biblical text. The reader assigns meaning to a text in interaction with other texts he knows (Van Wolde 1989:47). Hymnographers as readers of the Bible interpret passages from Genesis by using Psalms, Prophets and especially the
New Testament. They combine images and texts from different parts of the Bible in the depiction of the liturgical event. The biblical text is perceived both historically and eschatologically. Biblical phrases and images are arranged in a timeless florilegium, allowing the believer to anchor his or her presence not only in the past biblical event (Gârbacea 2018:205), but also in the eternal life to which he or she is called by God.

\section{Acknowledgements}

The author thanks Prof. Sysse Gudrun Engberg for providing the critical text of the paroimiai from Genesis 2-3.

\section{Competing interests}

The author declares that he has no financial or personal relationships that may have inappropriately influenced him in writing this article.

\section{Author's contributions}

C.H.O. is the sole author of this research article.

\section{Ethical considerations}

This article followed all ethical standards for research without direct contact with human or animal subjects.

\section{Funding information}

This research received no specific grant from any funding agency in the public, commercial or not-for-profit sectors.

\section{Data availability}

Data sharing is not applicable to this article as no new data were created or analysed in this study.

\section{Disclaimer}

The views and opinions expressed in this article are those of the author and do not necessarily reflect the official policy or position of any affiliated agency of the author.

\section{References}

Aubineau, M. (ed.), 1972, Hésychius de Jérusalem et al.: Homélies pascales (cinq homélies inédites), SC 187, Éditions du Cerf, Paris.

Azar, M.G., 2015, 'Prophetic Matrix and theological paradox: Jews and Judaism in the Holy Week and Pascha observances of the Greek Orthodox church', Studies in Christian-Jewish Relations 10(1), 1-27. https://doi.org/10.6017/scjr.v10i1.8658

Boicu, D., 2017, Monarhia constantiniană între arhetip divin şi construct eusebian, Andreiana \& ASTRA Museum, Sibiu.

Brenton, L.C.L. (transl.), 1870, The Septuagint version of the Old Testament: English translation, Samuel Bagster and Sons, London.

Brottier, L. (ed.), 1998, Jean Chrysostome: Sermons sur la Genèse, SC 433 (Sources Chrétiennes 433), Éditions du Cerf, Paris.

Bucur, B.G., 2007, 'Exegesis of Biblical Theophanies in Byzantine Hymnography: Rewritten Bible?', Theological Studies 68(1), 92-112. https://doi. org/10.1177/004056390706800105

Bucur, B.G., 2017, 'Anti-Jewish Rhetoric in Byzantine Hymnography: Exegetical and theological contextualization', Saint Vladimir's Theological Quarterly 61(1), 39-60.

Charalampidis, C.P., 1995, The dendrites in Pre-Christian and Christian historicalliterary tradition and iconography, 'L'ERMA' di BRETSCHNEIDER, Roma. 
Costache, D., 2009, 'Byzantine Insights into Genesis 1-3: St Andrew of Crete's Great Canon', Phronema 24, 35-50.

Costache, D., 2020, 'Andrew of Crete's Great Canon, Byzantine Hermeneutics, and Genesis 1-3', in A. Mellas \& S. Gador-Whyte (eds.), Hymns, homilies and hermeneutics in Byzantium, Byzantina Australiensia 25, pp. 67-85, Brill, Leiden.

Daniélou, J., 1961, Les symboles chrétiens primitifs, Editions du Seuil, Paris.

Donner, H., 1977, 'Der Felsen und der Tempel', Zeitschrift des Deutschen PalästinaVereins $93,1-11$.

Frolow, A., 1961, La relique de la vraie croix. Recherches sur le développement d'un culte, Archives de l'Orient Chretien 78, Institut Français d'Études Byzantines, Paris.

Gamble, H.Y., 1995, Books and readers in the early Church. A history of Early Christian texts, Yale University Press, New Haven, CT.

Gârbacea, R., 2018, 'De la exegeza textului biblic la teologia sărbătorii. Exemplul une omilii pseudo-hrisostomiene la Nașterea Domnului', in A. Ioniță \& D. Mihoc (eds.) Sfânta Scriptură în Biserică și istorie, pp. 198-209, Andreiana \& ASTRA Museum, Sibiu.

Geyer, P., 1898, Itinera hierosolymitana saecvli IIII-VIII, CSEL 39, Tempsky, Wien.

Gifford, E.H. (transl.), 1894, 'S. Cyril of Jerusalem: The catechetical lectures 13 $\mathrm{NPNF}^{2}$ ', in P. Schaff \& H. Wace (eds.), S. Cyril of Jerusalem, S. Gregory Nazianzen vol. 7, pp. 82-93, Christian Literature Company, New York, NY.

Grosdidier de Matons, J. (ed.), 1967, Romanos le Mélode: Hymnes, tome IV Nouveaux Testament (XXXII-XLV), SC 128, Éditions du Cerf, Paris.

Høeg, C. \& Zuntz, G. (eds.), 1940, Prophetologium, vol. 1, fasc. 2, Ejnar Munksgaards Forlag, Copenhagen.

Holder, A. (ed.), 1889, Inventio Sanctae Crucis, In Aedibus B. G. Teubneri, Lipsiae.

Holmes, M.W., 2011-2013, The Greek New Testament: SBL Edition, Logos Bible Software \& Society of Biblical Literature, Logos Bible Software Society of Biblical Literature, Atlanta, GA.

Ioniță, A., 2019, 'Byzantine liturgical hymnography: A stumbling stone for the JewishOrthodox Christian dialogue', Review of Ecumenical Studies 11(2), 253-267. Orthodox Christian dialogue', Review of
https://doi.org/10.2478/ress-2019-0018

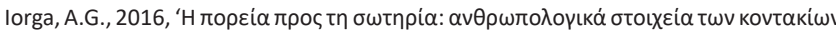
tou P $\omega \mu$ avoú tou M $\varepsilon \lambda \omega \delta$ oú [The course to salvation: anthropological elements of the kontakia of Romanos the Melodist]', PhD thesis, Aristotle University of the kontakia of Romanos the Melodist]', PhD thesis, Aristotle University of
Thessaloniki, viewed 23 June 2021, from https://ikee.lib.auth.gr/record/296088/ files/GRI-2018-21015.pdf.

Köpf, U., 1990, 'Kreuz IV. Mittelalter', in G. Müller, H. Balz, J.K. Cameron, B.L. Hebbletwaite \& G. Krause (eds.), Theologische Realenzyklopädie, vol. 19, pp. 732-761, De Gruyter, Berlin.

Krueger, D., 2014, Liturgical subjects: Christian ritual, biblical narrative, and the formation of the self in Byzantium, University of Pennsylvania Press, Philadelphia, PA.

Küchler, M., 2007, Jerusalem. Ein Handbuch und Studienreiseführer zur Heiligen Stadt Vandenhoeck \& Ruprecht, Göttingen.

Lenten Synaxarion, 2016, Lenten Synaxarion: Sunday of the veneration of the cross, 2016, viewed 01 February 2021, from https://orthochristian.com/92050.html.

Liddell, H.G., Scott, R., Jones, H.S. \& McKenzie, R., 1996, A Greek-English lexicon, Clarendon Press, Oxford.

Mary, M. \& Ware, K. (transl.), 1978, The Lenten Triodion, translated from the original Greek by Mother Mary and Archimandrite Kallistos Ware, Faber \& Faber, London.
Mary, M. \& Ware, K. (transl.), 1979, The Lenten Triodion. Supplementary texts, translated from the original Greek by Mother Mary and Metropolitan Kallistos of Diokleia, Monastery of the Veil of the Mother of God, Busy-en-Othe, of Diokleia
France.

Mellas, A., 2017, 'Liturgical emotions in Byzantine Hymns: Reimagining Romanos the Melodist's On the Victory of the Cross', Phronema 32(2), 49-75.

Migne, J.-P. (ed.), 1862, Patrologiae cursus completus: Series graeca, vol. 13, Migne, Paris.

Migne, J.-P. (ed.), 1863, Patrologiae cursus completus: Series graeca, vol. 87/3, Migne, Paris.

Miller, J., 2010, 'The Prophetologion: The Old Testament of Byzantine Christianity?', in P. Magdalino \& R. Nelson (eds.), The Old Testament in Byzantium, pp. 55-76, Dumbarton Oaks Research Library and Collection, Dumbarton Oaks, Washington, DC.

Mourtzios, I., 2019, 'Fenomenul antisemitismului și Biserica Ortodoxă', in A. Ioniță (ed.), Imnografia liturgică bizantină. Perspective critice, Studia Oecumenica 13, pp. 39-51, Presa Universitară Clujeană, Cluj-Napoca.

Mratschek, S., 2000, 'Codices vestri nos sumus: Bücherkult und Bücherpreise der christlichen Spätantike', in A. Haltenhoff \& F.H. Mutschler (eds.). Hortus Litterarum Antiquarum, pp. 369-380, Universitätsverlag C. Winter, Heidelberg.

Pentiuc, E.J., 2014, The Old Testament in Eastern Orthodox Tradition, Oxford University Press, New York, NY.

Rahlfs, A. (ed.), 1979, Septuagint: With Logos morphology, electronic edition, Deutsche Bibelgesellschaft, Stuttgart.

Ringgren, H., Nielsen, K. \& Fabry, H.-J., 2001, 'yy', in G.J. Botterweck (ed.), D.E. Green (transl.), Theological Dictionary of the Old Testament, vol. 11, pp. 265-278, William B. Eerdmans Publishing Company, Cambridge.

Roberts, A., Donaldson, J. \& Coxe, A.C. (eds.), 1885, The Apostolic fathers with Justin Martyr and Irenaeus, vol. 1, Christian Literature Company, Buffalo, NY.

Robinson, J.A. (transl.), 1920, St Irenaeus: The demonstration of the Apostolic preaching, Society for Promoting Christian Knowledge, London.

Schmemann, A., 1990, Great Lent, St. Vladimir's Seminary Press, Crestwood, NY.

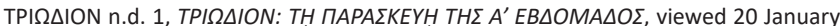
2021, from https://glt.goarch.org/texts/Tri/t44.html.

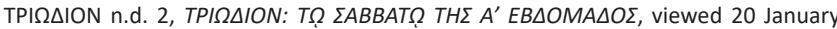
2021, from https://glt.goarch.org/texts/Tri/t43.html.

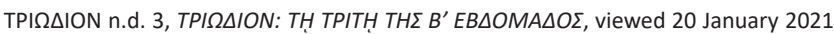
from https://glt.goarch.org/texts/Tri/t40.html.

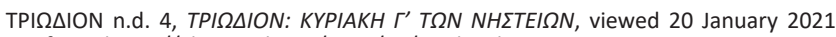
from. https://glt.goarch.org/texts/Tri/t28.html.

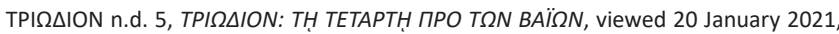
from https://glt.goarch.org/texts/Tri/t11.html.

Van Wolde, E., 1989. 'Trendy intertextuality?', in S. Draisma (ed.), Intertextuality in biblical writings, pp. 43-49, Uitgeversmaatschappij J.H. Kok, Kampen.

Wallraff, M., 2013, Kodex und Kanon. Das Buch im frühen Christentum, De Gruyter Berlin.

Way, S.A.C. (transl.), 1963, Saint Basil: Exegetic homilies, FOC 46, The Catholic University of America Press Washington, DC 